\title{
Occurrence of Chlorine Resistant Bacteria in Drinking Water Filtration Plants of Rawalpindi City, Pakistan
}

\author{
Mehrin Nishad Khan, Aneela Taj ${ }^{*}$, Rashida Bano, Najeeb Ullah, Saifullah Khan
}

Centres of Excellence in Science and Applied Technologies, Islamabad, Pakistan

Email address:

idnchr@gmail.com (A. Taj)

${ }^{*}$ Corresponding author

\section{To cite this article:}

Mehrin Nishad Khan, Aneela Taj, Rashida Bano, Najeeb Ullah, Saifullah Khan. Occurrence of Chlorine Resistant Bacteria in Drinking Water Filtration Plants of Rawalpindi City, Pakistan. Frontiers in Environmental Microbiology. Vol. 7, No. 1, 2021, pp. 6-14.

doi: $10.11648 /$ j.fem.20210701.12

Received: November 21, 2020; Accepted: December 9, 2020; Published: March 9, 2021

\begin{abstract}
Waterborne bacterial infections are mainly caused by the direct transmission of pathogenic bacteria to the host through DW. Chlorination of DW is critical to prevent the water supplies from bacterial pathogens. In present study, microbiological quality of DW provided through filtration plants to Rawalpindi City was investigated. Experimentations were designed to screen bacterial tolerance to the added Chlorine, and to subsequent study the antibiotic sensitivity of isolated bacteria. A total of 107 water samples were collected. Out of which, 57.95\% were found satisfactory for human consumption. $\mathrm{pH}$ determination revealed that $18.70 \%$ of the samples has $\mathrm{pH}$ in the range of 8.0 to 8.9 . TDS analysis showed $14.01 \%$ of samples above the standard HDL $(500 \mathrm{mg} / \mathrm{L})$. Furthermore, $13.34 \%$ of the samples showed the highest load (351 to $1800 \mathrm{CFU} / 100 \mathrm{~mL}) \mathrm{of}$ fecal coliforms. Ciprofloxacin and Tetracycline were found to be the most effective antibiotics against the isolated pathogens. These bacterial strains were also able to tolerate $1 \mathrm{mg} / \mathrm{L}$ of Chlorine. Present study revealed the presence of Chlorine and antibiotic resistant bacteria in DW, which poses a great health risk to the consumers. In conclusion, it is recommended to boil the DW, as it effectively kills all the bacteria in addition to chlorination.
\end{abstract}

Keywords: Chlorination, Chlorine Resistance, Drinking Water, Filtration Plants, Waterborne Bacteria

\section{Introduction}

Water is an essential component for all forms of life and is vital to sustain life on earth [1,2]. Accessibility and availability of fresh and clean water is a key to sustainable development and an essential element in health [3]. Water free from microorganisms especially pathogenic bacteria is a fundamental requirement for human life, personal hygiene and for drinking. However, all available water is not fit for human consumption [2, 4-6]. As per WHO reports the mortality rate of water associated diseases exceeds 5 million people per year. Among these, $>50 \%$ of intestinal infections are caused by the consumption of drinking water (DW) possessing microbial contamination $[5,7]$.

Pollution of water occurs when water sources such as ground water, ponds, rivers, and water distribution channels are contacted by pathogenic bacteria, viruses, fungi, protozoans and industrial toxic chemicals [8]. Coliform bacteria in DW are the indication of animal and human fecal contamination [9]. Water contamination rates are highest in the rainy seasons when microorganism rapidly grow and disperse in the water bodies. Lack of improper water treatment, facilities attribute to the spread of water borne diseases. In addition to this, DW distribution system is very poor as water channels and drainage lines run in parallel which hinder the provision of the good quality water $[10,11]$.

As far as DW quality is concerned, Pakistan ranks at number 80 among 122 nations. Thus proving that pollution of DW is one of the major threats for the public health in Pakistan. DW sources, both surface and groundwater are found contaminated with coliforms, toxic metals and pesticides throughout the country. In other words microbial and chemical pollutants are the main sources responsible exclusively and/or in combination for various public health problems $[12,13]$. This is also supported by a study conducted by Pakistan Council for Research in Water Resources covering 64 Tehsils in four provinces. The results of DW quality from 23 major cities revealed that the water resources of Pakistan are $27-$ 
$100 \%$ contaminated with bacteria $[13,14]$.

Chlorination is practiced at most of the filtration plants as a mean of water disinfection, before it is supplied to the public via distribution network $[15,16]$. Low cost and effectiveness of chlorine against pathogenic microorganisms has made it a chemical of choice in many countries including Pakistan [17]. Although, addition of chlorine is a common practice however, it is not sufficient to ensure the safety of water. Detection of any disinfectant residue reduces the microorganism count and frequency at the consumer's tap. Furthermore, DW Chlorine residues have long been recognized as an excellent indicator for accessing water quality in the distribution networks [1618]. Therefore, the maintenance of chlorine residues is needed at all points in any distribution system $[16,17,19]$.

The current study was designed to assess the quality of chlorinated drinking water supplied to the different parts of the city through the bacterial tolerance to the added Chlorine.

\section{Materials and Methods}

\subsection{Study Area}

Rawalpindi is the fourth largest city of Pakistan and is the third largest metropolitan city of Pakistan. It is situated on the Pothohar Plateau, adjacent to Islamabad, the capital city of Pakistan. It has GPS coordinates of $33^{\circ} 37^{\prime} 33.8052^{\prime \prime} \mathrm{N}$ and $73^{\circ} 4$ ' 17.1912" E and elevation of $508 \mathrm{~m}(1,667 \mathrm{ft})$. Population of this city according to the 2017 census is $2,098,231$. The weather is highly variable due to the proximity of the city to the foothills of Himalayas. The city features a humid subtropical climate (Kỏppen: Cwa) with hot and wet summers, a cooler and drier winter. It experiences on an average 91 thunderstorms per year. Strong windstorms are frequent in the summer during which wind gusts $176 \mathrm{~km} / \mathrm{h}$ (109 mph) have been reported by Pakistan Meterological Department. Such conditions (wind/thunder storm) often lead to damage of infrastructure. The main source of water for the city are ground and surface water, Khanpur and Rawal Dams, and 270 tube wells $[20,21]$.

\subsection{Sample Collection}

A total of 107 water samples were randomly collected from different Water and Sanitation Agency (WASA) filtration plants Water sampling was carried out during October, 2016 to May, 2017 in the presence of WASA inspector. Approximately 100 $\mathrm{mL}$ of water was collected in sterile $300 \mathrm{~mL}$ glass bottles. Taps were turned on full and water was allowed to flow for at least 1 minute. Subsequently, taps were sterilized with cotton soaked in spirit, water was again allowed to flow for few seconds. Sample bottles were filled with gentle flow of water and then capped immediately. Collected samples were then transported to the laboratory for microbiological processing.

\subsection{Media \& Chemicals}

Unless otherwise stated, all the bacteriological media, and antibiotic discs were purchased from Oxoid, Basingstoke, Hampshire, UK. Chemicals used for the bacterial identification were obtained from Merck, Darmstadt, Germany.

\subsection{Physiochemical Analysis}

All collected samples were processed for determination of $\mathrm{pH}$ and total dissolved solids (TDS) using $\mathrm{pH}$ meter (Oakton, U- Tech Instruments Malaysia) and observations were recorded for further analysis.

\subsection{Bacteriological Analysis}

\subsubsection{Enumeration of Coliforms by Most Probable Number (MPN) Test}

In order to screen the presence of total and fecal coliforms, collected water samples were processed through MPN method. The test procedure included three phases namely presumptive, confirmative and completed test.

Presumptive test: Each water sample was divided into 3 tubes of each containing 10,1 and $0.1 \mathrm{~mL}$ respectively. $10 \mathrm{~mL}$ sample was inoculated in double strength Lactose broth (LB-2X) while, 1 and $0.1 \mathrm{~mL}$ of the samples were inoculated in the single strength Lactose broth (LB-1X). All the inoculated tubes were incubated at $37^{\circ} \mathrm{C}$ for $24-48 \mathrm{hrs}$. Media tubes showing the presence of growth in terms of turbidity (with or without gas) were subjected to the confirmed test.

Confirmed test: All test tubes found turbid were gently shaken and one loopful of this culture was inoculated on to EMB (Eosin Methylene Blue) agar. Media plates were incubated at $37^{\circ} \mathrm{C}$ for $24 \mathrm{hrs}$. Subsequently, plates were observed for the growth and development of green metallic sheen.

Completed test: To confirm the presence of E. coli, single colony showing green metallic sheen was selected. Half of the selected colony was aseptically inoculated in Lactose broth containing Derhum tube to reconfirm the positive lactose fermentation. While Nutrient agar slants inoculated with rest of the selected colony and incubated at $37^{\circ} \mathrm{C}$ were further proceeded for the identification of isolates. Finally, the isolated organisms were identified by performing standard microbiological methods (Cellular morphology including Gram reaction \& standard biochemical tests).

\subsubsection{Detection of Other Gram Negative Bacteria}

For the isolation of other Gram negative pathogens, $0.1 \mathrm{~mL}$ of each water sample was separately inoculated on the sterile MacConkey agar plates. All inoculated plates were incubated at $37^{\circ} \mathrm{C}$ for $24 \mathrm{hrs}$. Bacterial identification was carried out by performing standard microbiological methods including Gram reaction and biochemical tests. All experiments were run in duplicates.

\subsection{Antimicrobial Susceptibility Testing}

Antimicrobial susceptibility testing was done on Muller-Hinton agar using disk diffusion technique according to Kirby-Bauer method [22]. Antimicrobial agents tested were: Augmentin $(30 \mu \mathrm{g})$, Cefixime $(5 \mu \mathrm{g})$, Ceftriaxone $(30$ 
$\mu \mathrm{g})$, Tetracycline $(30 \mu \mathrm{g}), \quad$ Ciprofloxacin $\quad(5 \mu \mathrm{g})$, Sulphamethox/trimethoprim $(25 \mu \mathrm{g})$, Meropenem $(10 \mu \mathrm{g})$, Oxacillin $(30 \mu \mathrm{g})$, Nalidixic Acid $(30 \mu \mathrm{g})$ and Chloramphenicol $(30 \mu \mathrm{g})$. After $18 \mathrm{~h}$ incubation at $37^{\circ} \mathrm{C}$, the size of the zone of inhibition was measured and interpreted by comparing with the standard antibiotic sensitivity chart to determine their resistance patterns. All experiments were run in duplicates.

\subsection{Screening of Chlorine Resistant Bacteria}

To check the chlorine tolerance of the bacteria isolated from aforementioned samples. All bacterial strains were separately inoculated on nutrient agar supplemented with pure grade Sodium hypochlorite (Daejung, Korea) $(1 \mathrm{mg} / \mathrm{L})$ plates. Incubation of these plates was carried out at $37^{\circ} \mathrm{C}$ for $24 \mathrm{hrs}$. Subsequently, plates were observed for bacterial growth. The experiment was run in triplicates. Chlorine concentration used in this study was the actual concentration used to disinfect water before its supply to households of the city.

\subsection{Statistical Analysis}

Data obtained was analyzed through calculation of mean, proportions, percentages and graphs and tables were prepared for data visualization. The bacteriological counts recorded were compared with the WHO guidelines for drinking water.

\section{Results and Discussion}

\subsection{Collection and Water Potability Status}

Rawalpindi is the third largest city of Pakistan, located near the capital city of Islamabad, in the province of Punjab. Sufficient quantity of DW supply in this city is the responsibility of WASA. WASA (Rawalpindi) was created with the mandate to provide sufficient quantity of quality DW, sewerage treatment services and for maintaining drainage facilities of the city. There are two main sources of DW available in the city i.e. ground water and surface water. Ground water is obtained with the help of 270 tube wells, supplying approximately 26 million gallon of water per day (MGD) to the city. Whereas surface water is supplied from Khanpur Dam through Sangjiani Water Treatment Plant and Rawal Lake through a 23-MGD Rawal Lake Filtration Plant $[13,23]$.

The study reported herein is the first study in Pakistan that focuses on the possible applications of excessive usage of Chlorine to disinfect DW directly on bacteria residing in it. It further provides an overview of the impacts on human health due to consumption of Chlorinated water. These include the infections caused by Chlorine resistant bacteria and other possible biochemical manifestations in human host caused by continuous intake of Chlorine rich water. Literature search revealed various studies on both Gram positive and Gram negative bacteria isolated from DW [14-18]. Contrary to that, current study was focused on the Gram negative (Gram -ve) bacteria including total and fecal coliforms.

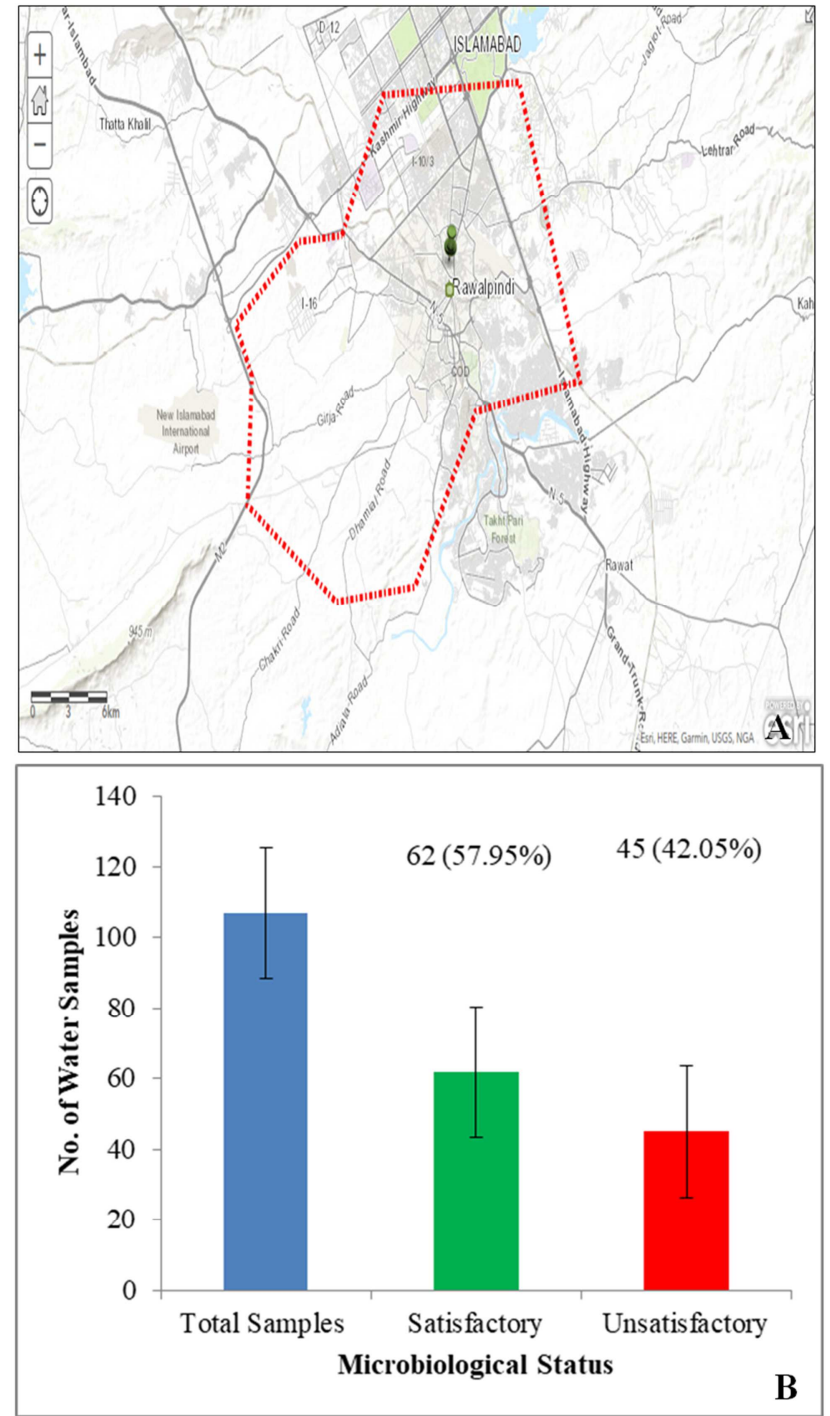

Figure 1. (A) Location map of Rawalpindi city for water sample collection; (B) Microbiological Status of the collected water samples.

To check the quality of DW, a total of 107 filtration plants of Rawalpindi city were considered (Figure 1A). The map for sampling sites was drawn using ArcGIS tools. Out of these, 62 samples $(57.95 \%)$ were found satisfactory for human consumption. However, 45 samples $(42.05 \%)$ were found microbiologically contaminated either with fecal coliforms and/or with other Gram -ve bacteria, thus unfit for the drinking purpose (Figure 1B). The results of the present study are in line with previous findings in which bacterial contamination of DW was reported in Rawalpindi and Islamabad cities [13, 23-25]. Thus, the present study highlights the significance of the microbiological examination of the DW before human consumption. For the reason that, fecal coliforms and most of the other Gram -ve bacteria isolated in present study are well-known principle pathogens of human gastrointestinal tract (GIT) infections. These results obtained can be further explained by the fact that these water borne pathogens are not only responsible for causing infections in some individuals. Nevertheless, there are reports for sudden increase in number of coliform bacteria in DW 
distribution systems in various parts of the world that have led to the occurrence of an infectious outbreak in human population [26-29].

\subsection{Physiochemical Quality}

This set of experiment was conducted to evaluate the $\mathrm{pH}$ of the collected water samples. Results of this experiment indicated that $17.75 \%$ water samples showed $\mathrm{pH}$ ranging 6.0 to 6.9 , whereas 68 samples $(63.55 \%)$ showed $\mathrm{pH}$ from 7.0 to 7.9. It is interesting to mention that $18.70 \%$ of samples yielded $\mathrm{pH}$ in the range of 8.0 to 8.9 (Figure $2 \mathrm{~B}$ ). Therefore, the later cohort of water samples was found beyond the highest desirable limit (HDL) set by WHO i.e. 8.5.
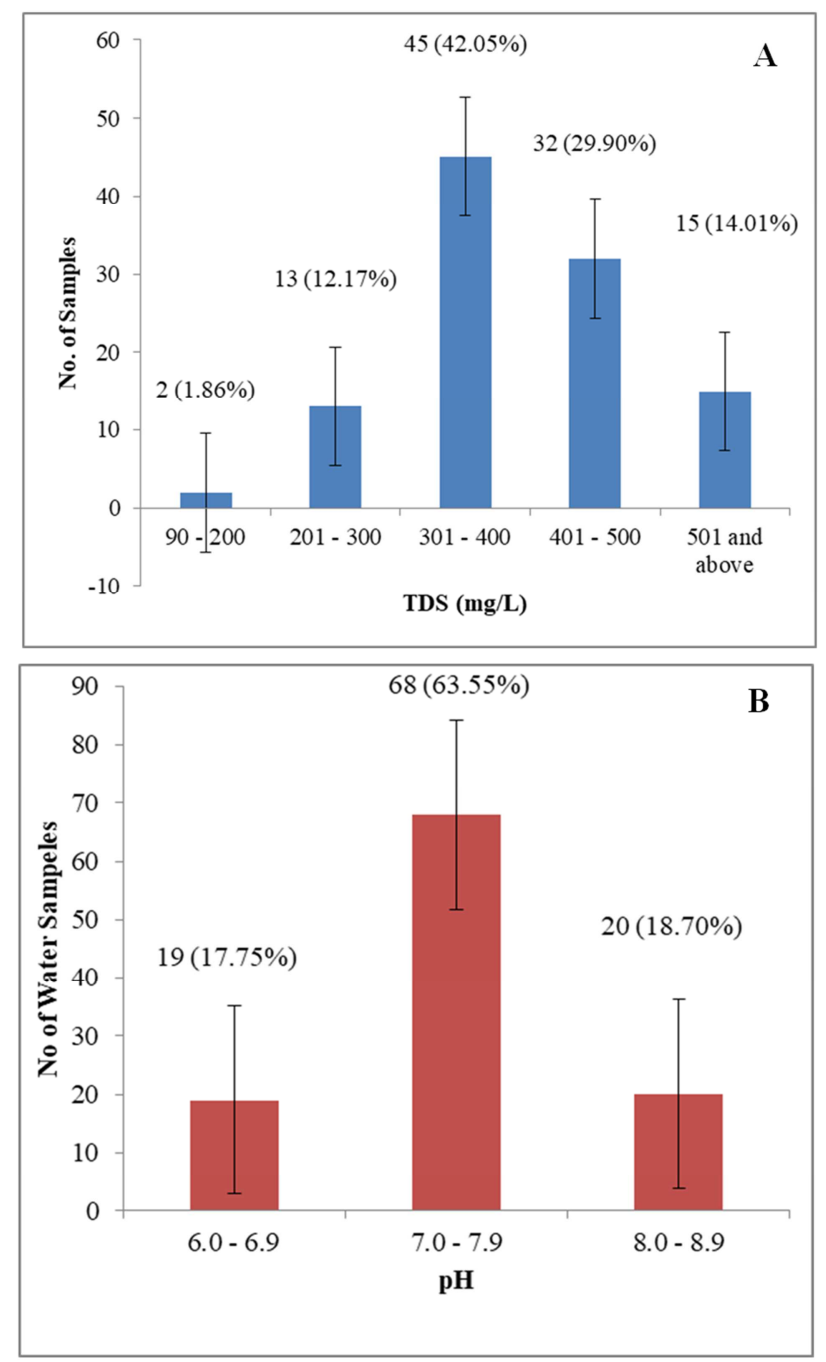

Figure 2. (A) Total dissolved solids (TDS) profile of water samples; (B) $p H$ profile of water samples.

In order to determine the TDS in the collected DW samples, another set of experiment was performed. Out of 107 collected water samples, $15(14.01 \%)$ samples were found above the standard HDL of $500 \mathrm{mg} / \mathrm{L}$ (Figure 2A). In contrast, 2 (1.86\%) of the samples yielded the lowest TDS values i.e. 90 to 200 $\mathrm{mg} / \mathrm{L}$. Furthermore, 201 to $300 \mathrm{mg} / \mathrm{L}$ and 401 to $500 \mathrm{mg} / \mathrm{L}$ of
TDS were found in $13(12.17 \%)$ and $32(29.90 \%)$ water samples respectively. Interestingly, $45(42.05 \%)$ of the samples indicated the presence of TDS as 301 to $400 \mathrm{mg} / \mathrm{L}$.

It is striking that, $14.01 \%$ of the DW samples yielded total TDS ranging $>500 \mathrm{mg} / \mathrm{L}$ which is beyond the standard HDL of $500 \mathrm{mg} / \mathrm{L}$ (Figure 2A). In addition, the results of the physiochemical analysis highlighted that $18.70 \%$ of DW samples has elevated $\mathrm{pH}$ i.e 8.6 to 8.9 which is also higher than WHO standard limit i.e. 8.5 (Figure 2B). The possible reason for the elevations in the physiochemical aspects of DW may be due to bacterial growth and multiplication in it. It is worth to mention herein that temperature monitoring at these filtration plants was beyond the scope of the present study, nevertheless temperature, in combination with TDS, $\mathrm{pH}$ and other physical factors like (infrastructure, water pipeline conditions and rusting) also strongly aid in the survival of water borne pathogens in DW. Evidence also suggest that DW physiochemical imbalance also leads to the corrosion of water mains and interior plumbing systems. This happens when biofilms influence the local chemistry of distribution system surfaces and leads to physiochemical imbalance [30]. Consequently, failure to control to these can result in the survival of different bacterial pathogens in the systems [23, 30]. Research studies have shown that biofilms developed more rapidly on pipes composed of iron, it hence proves that pipe material could be a source of nutrition for certain bacteria in DW [41, 42]. Growth of Lagionella spp was found to be associated with rubber gaskets used in water mains [43]. Microorganisms such as Pseudomonas aeruginsa, Chromobacter spp, Enterbacter aerogenes and Klebsiella pneumoniae have dependent growth pattern on joint packing materials in water distribution system [44]. In the present study, it can be concluded that bacteria may be using the elevated solids as nutrients to multiply in the suitable $\mathrm{pH}$. Moreover, it definitely adversely affects taste, odor and appearance of the DW [32].

\subsection{Bacteriological Quality}

In this experiment, water samples were evaluated for the presence of fecal coliforms and other Gram negative bacteria. Results of MPN test indicated that 45 (42.05\%) samples showed the presence of fecal contamination (Figure 1B). Out of these 45 contaminated water samples, 31 (68.89\%) samples yielded the bacterial load as 5 to $100 \mathrm{CFU} / 100 \mathrm{~mL}$. Whereas, $6(13.34 \%)$ samples showed coliforms ranged from 101 to 200 CFU/ 100mL (Figure 3). Further analysis of the results of the present study indicated that, $2(4.45 \%)$ of DW samples revealed the presence of coliforms bacteria ranging from 201 to $350 \mathrm{CFU} / 100 \mathrm{~mL}$. It is significant to mention herein that 6 (13.34\%) of the DW samples of Rawalpindi city filtration plants yielded the highest load of the fecal coliforms in range of 351 to $1800 \mathrm{CFU} / 100 \mathrm{~mL}$ (Figure 3). Nonetheless, such high numbers of coliforms bacteria significantly highlight the extreme health concern for the population of the city. 


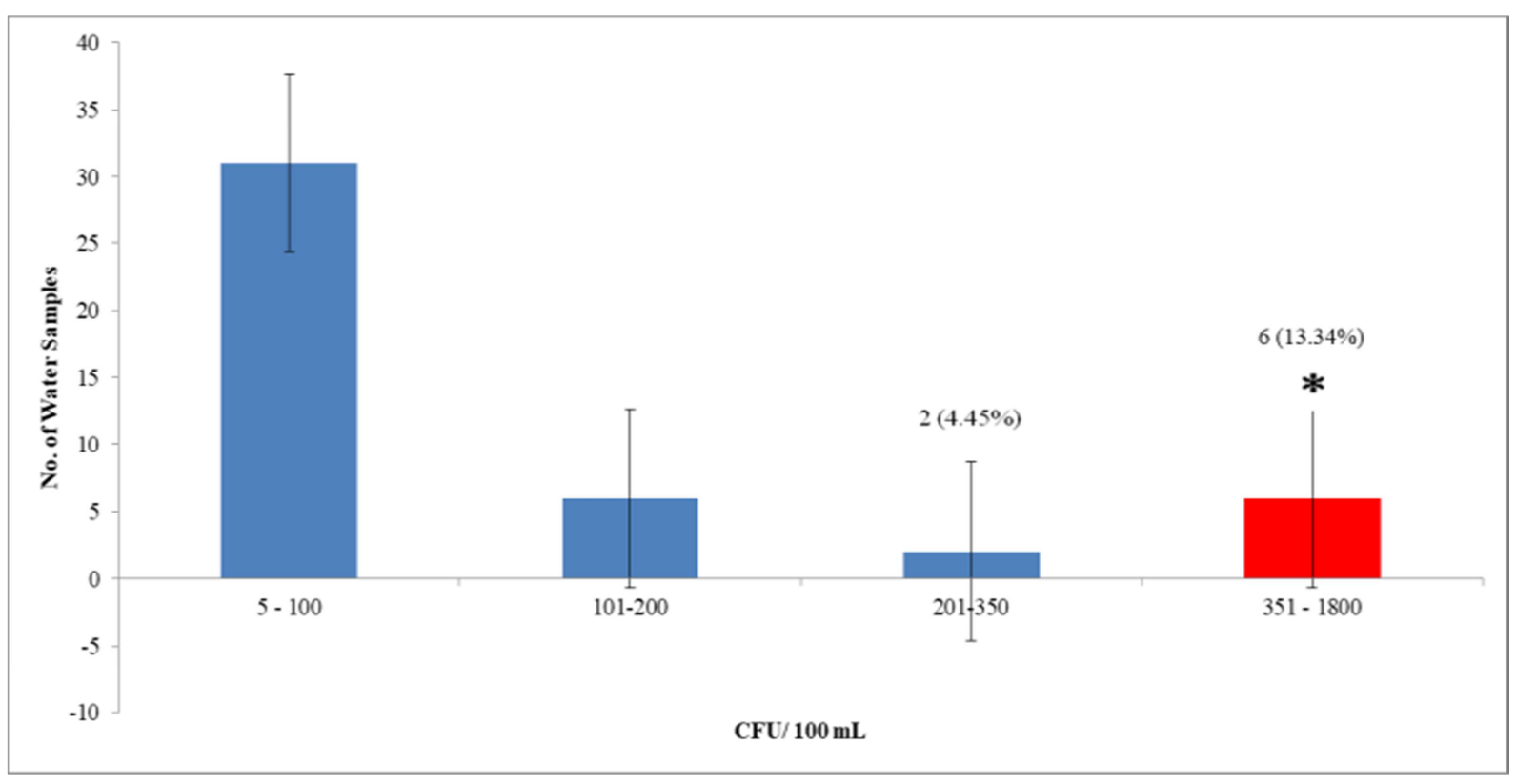

Figure 3. Quantification of fecal contamination (CFU/100ml) of water samples.

Furthermore, the most frequently isolated bacterial strains (i.e. both coliforms and other Gram -ve bacteria) are summarized in Figure 4.

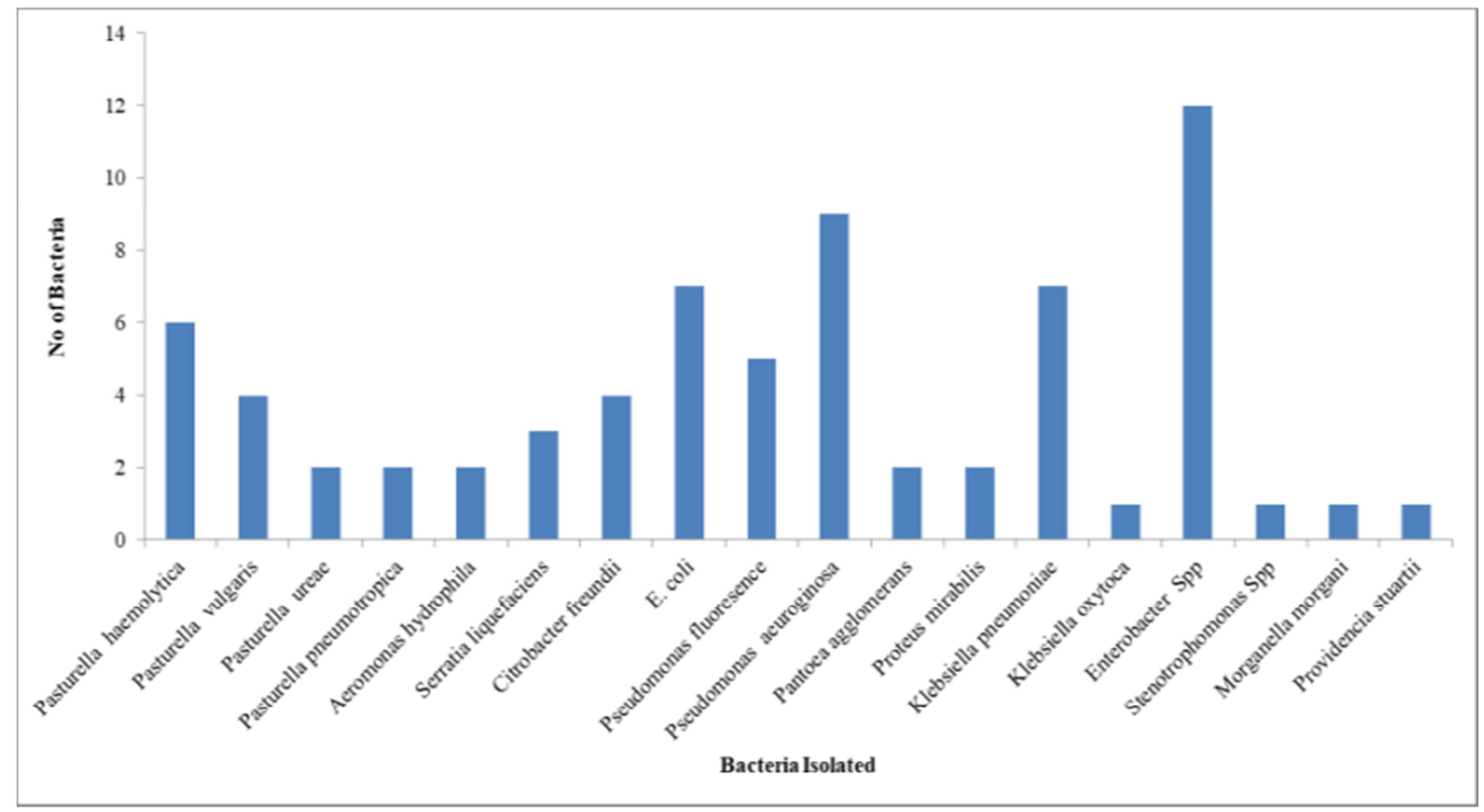

Figure 4. Pictorial representation of the total bacterial strains isolated.

The MPN analysis showed diversified response. It was interesting to note that $13.34 \%$ of DW samples showed the highest bacterial load i.e. ranging from 351 to $1800 \mathrm{CFU} / \mathrm{mL}$ (Figure 3). Whereas, other DW sample cohorts revealed the presence of fecal coliforms load in the range from 5 to 350 $\mathrm{CFU} / \mathrm{mL}$. Thus, it is justified to conclude that elevated number of bacterial pathogen in DW is an extreme health concern for the consumers. Although, no visible microbial contamination was detected at any filtration plant taps during the sampling period; however, results of the MPN experiment significantly highlights the deterioration of the DW quality as it flowed through the distribution network. The detection of fecal coliforms in DW is mainly associated with the unhygienic conditions, parallel lining of the DW and sewerage and insufficient water supply. Our findings are in accordance to other reports $[6,12,13,23-25,31]$ that indicated the presence of fecal coliforms in combination with other Gram -ve bacteria in the DW. Results of the present study are in part consistent with the previous research, which reported fecal contamination in distribution channels of Rawal Lake [32] and 
other water distribution channels and treatment plants of Rawalpindi city [33, 34].

The culturable count of other Gram -ve water borne bacteria was enumerated additionally (Figure 4). Further analysis of the results directed us to report the presence of a number of water borne bacteria that may also serve as possible pathogens to human host. It was significant to note that, Enterobacter Spp, Pseudomonas aerouginosa, Klebsiella pneumonia and E. coli are the most isolated bacterial strains from the DW samples. These results can be explained by the fact that aforementioned bacteria are known to cause vomiting, diarrhea, dysentery, gastroenteritis, other GIT illnesses and kidney problems [35-37] Therefore, consumption of DW contaminated with these pathogens poses serious health risk to the consumers.

\subsection{Antimicrobial Susceptibility Profile}

The above-mentioned bacterial isolation prompted us to evaluate the antibiotic resistance profile of the isolated DW borne bacterial pathogens, results of which are summarized in Table 1. This analysis indicated that, Pasturella ureae, S. liquefaciences, Citrobacter freundii, Proteus mirabilis,
Klebsiella pneumonia, Morganella morgani and Providencia stuartii were found moderately resistant to Ceftriaxone. However, $>80 \%$ of isolated bacterial pathogens were found resistant to Cefixime. In contrast, Sulphamethox/trimethoprim was effective against Pasturella vulgaris, Aeromonas hydrophila, S. liquefaciences, Proteus mirabilis, Stenotrophomonas Spp and Providencia stuartii. Augmentin showed inhibitory activity specifically against bacterial spp of Aeromonas hydrophila. Oxacillin and Meropenem showed moderate inhibition of Citrobacter freundii, E. coli and Ps. fluorescence. It is worth mentioning here that Ciprofloxacin and Tetracycline were the most effective antibiotics against the isolated waterborne pathogens. In contrast, Nalidixic acid was ineffective against $P$. pneumotropica, E. coli, Pantoea agglomerans and Providencia stuartii. Chloramphenicol, on the other hand revealed the sensitivity against Pasturella ureae, Pseudomonas fluorescence, Klebsiella oxytoca, Enterobacter Spp and Morganella morgani only (Table 1). Thus, these results highlight that Ciprofloxacin and Tetracycline are drug of choice against the infections caused by any of the bacterial pathogen isolated in present study.

Table 1. Antibiotic sensitivity profile of bacterial strains isolated from water.

\begin{tabular}{|c|c|c|c|c|c|c|c|c|c|}
\hline & $\begin{array}{l}\text { Pasturella } \\
\text { haemolytica }\end{array}$ & $\begin{array}{l}\text { Pasturella } \\
\text { vulgaris }\end{array}$ & $\begin{array}{l}\text { Pasturella } \\
\text { ureae }\end{array}$ & $\begin{array}{l}P . \\
\text { pneumotropica }\end{array}$ & $\begin{array}{l}\text { Aeromonas } \\
\text { hydrophila }\end{array}$ & $\begin{array}{l}S . \\
\text { liquefaciences }\end{array}$ & $\begin{array}{l}\text { Citrobacter } \\
\text { freundii }\end{array}$ & E. coli & $\begin{array}{l}\text { Ps. } \\
\text { fluoresence }\end{array}$ \\
\hline Total No of Isolates (n) & 06 & 04 & 02 & 02 & 02 & 03 & 04 & 07 & 05 \\
\hline Ceftriaxone & 100 & 100 & 50 & 100 & 100 & 34 & 25 & 100 & 100 \\
\hline Cefixime & 67 & 0 & 0 & 0 & 0 & 0 & 0 & 0 & 40 \\
\hline $\begin{array}{l}\text { Sulphamethox/ } \\
\text { trimethoprim }\end{array}$ & 34 & 100 & 50 & 0 & 100 & 100 & 75 & 85 & 0 \\
\hline Augmentin & 34 & 0 & 0 & 0 & 100 & 34 & 25 & 0 & 0 \\
\hline Ciprofloxacin & 100 & 100 & 100 & 100 & 100 & 100 & 75 & 85 & 100 \\
\hline Tetracycline & 50 & 100 & 100 & 100 & 100 & 100 & 75 & 85 & 100 \\
\hline Meropenem & 0 & 0 & 0 & 0 & 0 & 0 & 0 & 0 & 20 \\
\hline Nalidixic Acid & 17 & 100 & 50 & 0 & 100 & 100 & 75 & 0 & 20 \\
\hline Chloramphenicol & 0 & 0 & 50 & 0 & 0 & 0 & 0 & 0 & 100 \\
\hline
\end{tabular}

Table 1. Continued.

\begin{tabular}{|c|c|c|c|c|c|c|c|c|c|}
\hline & Ps. aeuroginosa & $\begin{array}{l}\text { Pantoea } \\
\text { agglomerans }\end{array}$ & $\begin{array}{l}\text { Proteus } \\
\text { mirabilis } \\
\end{array}$ & $\begin{array}{l}\text { K. } \\
\text { pneumoniae }\end{array}$ & $\begin{array}{l}\text { K. } \\
\text { oxytoca }\end{array}$ & $\begin{array}{l}\text { Enterobacter } \\
\text { Spp }\end{array}$ & $\begin{array}{l}\text { Stenotrophomonas } \\
\text { Spp }\end{array}$ & $\begin{array}{l}\text { Morganella } \\
\text { morgani }\end{array}$ & $\begin{array}{l}\text { Providencia } \\
\text { stuartii }\end{array}$ \\
\hline $\begin{array}{l}\text { Total No of } \\
\text { Isolates (n) }\end{array}$ & 09 & 02 & 02 & 07 & 01 & 12 & 01 & 01 & 01 \\
\hline Ceftriaxone & 100 & 100 & 50 & 71 & 100 & 100 & 100 & 0 & 0 \\
\hline Cefixime & 0 & 0 & 0 & 0 & 0 & 0 & 0 & 0 & 0 \\
\hline $\begin{array}{l}\text { Sulphamethox/ } \\
\text { trimethoprim }\end{array}$ & 23 & 0 & 100 & 71 & 0 & 59 & 100 & 0 & 100 \\
\hline Oxacillin & 0 & 0 & 0 & 0 & 0 & 0 & 0 & 0 & 0 \\
\hline Ciprofloxacin & 100 & 100 & 100 & 100 & 100 & 100 & 100 & 100 & 100 \\
\hline Tetracycline & 13 & 0 & 100 & 100 & 100 & 25 & 100 & 100 & 100 \\
\hline Meropenem & 0 & 0 & 0 & 0 & 0 & 9 & 0 & 0 & 0 \\
\hline Nalidixic Acid & 100 & 0 & 100 & 15 & 100 & 75 & 100 & 100 & 0 \\
\hline Chloramphenicol & 0 & 0 & 0 & 15 & 100 & 100 & 0 & 100 & 0 \\
\hline
\end{tabular}

*Numbers represent percent susceptible

Interestingly, our results revealed that Ciprofloxacin, Ceftriaxone and Tetracycline can effectively kill all the reported water borne bacteria isolated in this study. In contrast, all the rest of the antibiotics either showed moderate or no activity against these bacteria. Our findings are in part consistent with another study which reported the sensitivity of water borne thermo tolerant $E$. coli against Nalidixic acid and resistance against Augmentin [38]. The possible explanation of these findings could be the excessive and uncontrolled use of antibiotics significantly contributes in the dissemination of 
antibiotic residues in fresh water environment. Nonetheless, the antibiotic sensitivity pattern reported here uncovers a potential link and a greater risk of resistance genes transfer to other pathogenic bacteria. Taken together, this may worsen the diagnosis and treatment of infections caused by aforementioned bacteria.

\subsection{Prevalence of Chlorine Resistant Bacterial Pathogens}

This experiment was outlined to evaluate the ability of isolated pathogens tolerance against most commonly used disinfectant worldwide i.e. Chlorine. It is worth to mention herein that all the isolated bacterial strains were able to tolerate $1 \mathrm{mg} / \mathrm{L}$ of Chlorine. All isolates showed the growth in 24 hrs incubation in the presence of Chlorine. These results highlight the ineffectiveness of chlorine to be used as disinfectant in DW (Figure 5).

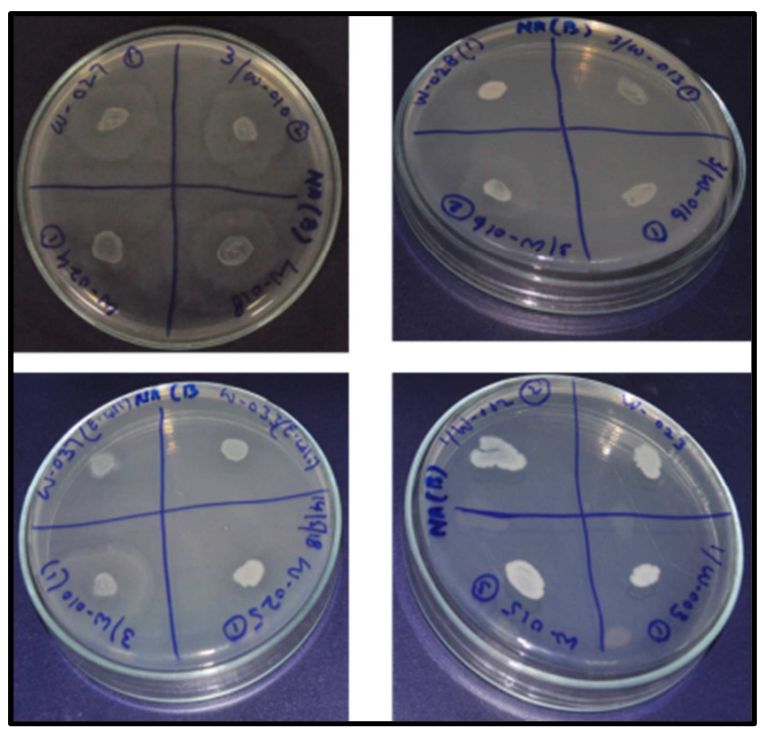

Figure 5. Chlorine resistance $(1 \mathrm{mg} / \mathrm{L})$ pattern in water isolates.

These findings are in line with another study in which Chlorine resistance of different bacteria isolated from water distribution system in Duhok, province of Iraq was reported [39]. Another possible explanation for the present findings may be that DW borne bacteria definitely has developed some underline mechanism to survive in the mentioned concentration of chlorine. Extensive literature search has revealed that very less attention has given to study the possible effects of excessive chlorinated water intake on human health. Therefore, the scientific community may also focus on this issue. Furthermore, booster chlorination doses to attain the bacterial survival mechanism in chlorinated water may be the reason for the compromised purity of DW. Evidence suggested that adverse effects related persistent intake of high concentrations of Chloride is attributed to increase the number of polymorphonuclear leukocyte and disturbed blood cell counts in full blood cell count analysis. Chlorine is one of the oxidizing substances that reduce the level of oxygen in the cells, increasing the risk of heart disease. Furthermore, teeth weakness and decay, inflammation of mouth lining, respiratory system illnesses including bronchitis, digestive system irritations including vomiting, chest pain, inflammation of pharynx, esophagus, and liver and intestinal tissues are the cardinal related risks of prolonged consumption of chlorinated water. In addition to that presence of positive correlation of developing colon, stomach, pancreas, liver, bladder and anal cancer and the exposure to chlorinated byproducts in drinking water is also a major point of concern [40].

\section{Conclusion}

Since sustained chlorinated DW consumption is attributed to the mild to severe complications of the cardinal systems of human body. Therefore, in conclusion it is recommended to regularly monitor Chlorine dosage to attain the DW disinfections. Furthermore, health risk to humans upon exposure to Chlorine tolerant bacterial contaminated DW may also be considered as development of resistance mechanism in bacteria. This may also contribute in alteration of antibiotic sensitivity profile of these bacteria. Thus serving as an additional factor to increase the pathogenicity of bacteria. In contrast, collectively these factors may narrow the treatment options for patients developed infection by these chlorine and antibiotic resistant DW bacteria. Lastly, it is strongly recommended to boil the DW, as it effectively kills all the bacteria in addition to chlorination.

\section{Acknowledgements}

The authors are grateful to Mr. Gulzar Ahmed Channa, Ms. Yasmeen and Mr. Owais Quadri who helped in Laboratory work.

\section{References}

[1] Moosa M E, Khan M A, Alalami U and Hussain A, 2015. Microbiological Quality of Drinking Water from Water Dispenser Machines. Int. J. Environ. Sci. Dev. 6 (9): 710-713.

[2] Khan A and Qureshi F R, 2018. Groundwater Quality Assessment through Water Quality Index (WQI) in New Karachi Town, Karachi, Pakistan. Asian. J. Water Environ. Pollut. 15 (1): 41-46.

[3] Third World Water Forum. Blockade, myth, illusion in development and cooperation, vol. 30, 2003.

[4] World Health Organization Guidelines for Drinking-Water Quality: 2005.

[5] Chauhan A, Goyal P, and Jindal T, 2017. Microbiological Evaluation of drinking water sold by roadside vendors of Delhi, India. Appl. Water. Sci, J. 7 (4): 1635-1644.

[6] Taj A, and Baqai R, 2007. Antimicrobial effects of Alum and Sulphur on bacteria isolated from Mineral and Hospital water. Pak. J. Infect. Dis. 16: 10-13.

[7] Seas C, Alarcon M, Aragon J C, Beneit S, Quinoez M, Guerra $\mathrm{H}$, and E. Gotuzzo, 2000. Surveillance of bacterial pathogens associated with acute diarrhea in Lima. Peru. Int. J. Infect. Dis. 4 (2): 96-99. 
[8] Arora D R, 2007. Textbook of Microbiology. 2nd ed. New Delhi: CBS Publishor \& Distributor. 1130-1131.

[9] Pelczar M J, Chan E C S, and Krieg N R, 2007. Microbiology. 5th ed. New Delhi: Tata McGraw Hill. 1253-1254.

[10] Patoli A A, Patoli B B, and Mehraig V, 2010. High prevalence of Multi-drug resistant Escherichia coli in drinking water samples from Hyderabad.” Gomal. J. Med. Sci. 8 (1).

[11] Kosek M, Bern C, and Guerrant R L, 2010. The global burden of diarrhoeal disease, as estimated from studies published between 1992 and 2000. Bull. World. Health. Organ. 81: 197204.

[12] Azizullah A, Khattak M N, Richter P, and Häder D P, 2011. Water pollution in Pakistan and its impact on public health: a review. Environ Int. 37 (2): 479-497.

[13] Hisam A, Rahman M, Kadir E, Tariq N A, and Masood S, 2014 Microbiological Contamination in Water Filtration Plants in Islamabad. J Coll Physicians Surg. 24 (5): 345-350.

[14] Ministry of Science and Technology. Pakistan Council of Research in Water Resources: water quality. Government of Pakistan. [Internet]. Available From: http://www.pcrwr.gov.pk/water\%20quality.aspx.

[15] WHO. Ontario Drinking Water Quality Standards, Objectives and Guidelines Technical Support Document for Ontario Drinking Water Quality Standards, Objectives and Guidelines. Ministry of the Environment. 2003.

[16] Ahmad M R, Ahmad A F, and Harendra S K, 2015. Assessment of microbiological quality of drinking water treated with chlorine in the Gwalior city of Madhya Pardesh, India. Afr. J. Environ. Sci. Technol. 9 (5): 396-401.

[17] Lienyao L, Chungsying L, and Shyang-Lai K, 2004. Saptial delivery of chlorine residual in a drinking water distribution system. J. Environ. Eng. 130 (11): 1263-1268.

[18] Olivieri V P, Snead M C, Kruse C W, and Kawata K M, 1986. Stability and effectiveness of chlorine disinfectants in water distribution system. Environ. Health. Persp. 69: 15-29.

[19] Kitazawa H, 2006. Keeping residual chlorine and decreasing unpleasant odor caused by disinfection of tap Water. Water Supp. 6 (2): 193-199.

[20] Climate: Rawalpindi-Climate graph, Temperature graph, Climate table. Climate- Data.org. Retrieved 7 September 2013.

[21] Weather History for Islamabad, Pakistan/ Weather Underground. Wunderground.com. Retrieved 22 November 2013.

[22] Bauer A W, Kirby W M M, Sherris J C, and Turck M, 1966. Antibiotic susceptibility testing by standard single disc method. Am. J. Clin. Pathol. 45 (4): 493-496.

[23] Hasmi I, Qaiser S, and Farooq S, 2012. Microbiological Quality of Drinking Water in Urban Communities, Rawalpindi, Pakistan. Desalin. Water. Treat. 41 (1-3): 240 -248.

[24] Hasmi I, Qaiser S, Asma S, Khan M T A, and Abbas S, 2011. Assessing Microbiological Safety of Drinking Water: A case study of Islamabad, Pakistan. In Proceedings of the Pakistan Engineering Congress World Water Day. 29-36.
[25] Mehmood S, Ahmed A, Ahmed A, Khalid N, Javed T, 2013. Drinking water quality in capital city of Pakistan. Sci. Rep. 2 (2): $1-6$.

[26] Earnhardt Jr K B, 1980. Chlorine-resistant coliform: The Muncie, Indiana experience, Paper 4-2. In American Water Works Association, Water Quality Technical Conference, Miami Beach, Fla.

[27] Goshko M A, Pipes W O, and Christina R R, 1983. Coliform occurrence and chlorine residual in small water distribution system. J. Am. Water. Works. Ass. 74 (7): 371-374.

[28] Hudson L D, Hanklin J W, and Battaglia M, 1983. Coliforms in a water distribution system: A remedial approach. J. Am. Water. Works. Ass. 75 (11) 564-568.

[29] Lowther E D, and Moser R H, 1984. Detecting and eliminating coliform regrowth, Paper 4B-4. In American Water Works Association, Water Quality Technical Conference, Denver.

[30] WHO. $\mathrm{pH}$ in Drinking-water: Background document for development of WHO Guidelines for Drinking-water Quality. Originally published in Guidelines for drinking-water quality (Vol. 2). Health criteria and other supporting information. 2003.

[31] Hydar S, Arshad M, Aziz J A, 2000. Evaluation of Drinking Water Quality in Urban Areas of Pakistan: A Case Study of Southern Lahore. Pak. J. Engg. Appl. Sci. 5: 16-23.

[32] Mashiatullah A, Chaudhary M Z, Khan M S, Javed T, and Qureshi R M, 2010. Coliform bacterial pollution in Rawal Lake, Islamabad and its feeding streams/river." Nucleus. 47 (1): 35-40.

[33] Farooq S, Hashmi I, Qazi I A, Qaiser S, and Rasheed S, 2008. Monitoring of Coliforms and chlorine residual in water distribution network of Rawalpindi, Pakistan. Environ. Monit. Assess. 140 (1-3): 339-347.

[34] Hashmi I, Farooq S, and Qaiser S, 2009. Incidence of fecal contamination within a public drinking water supply in Ratta Amral, Rawalpindi. Dsesalin. Water. Treat. 11 (1-3): 124-131.

[35] Walker CF, Black RE, 2010. Diarrhoea morbidity and mortality in older children, adolescents, and adults. Epidemiology \& Infection. 138 (9): 1215-1226.

[36] Khan S S, Tareen H, Jabeen U et al, 2015. Quality assessment of drinking water from the different colonies of Quetta city, Pakistan according to WHO Standards. Biol Forum. 7 (2) 699 702 .

[37] Memon M, Soomro M S, Akhtar M S, and Memon K S, 2011. Drinking water quality assessment in Southern Sindh (Pakistan). Environ. Monit. Assess. 177 (1-4): 39-50.

[38] Shar A H, Kazi Y F, and Soomro I H, 2009. Antibiotic Susceptibility of Thermo- Tolerant Escherichia coli 2 Isolated from Drinking Water of Khairpur City, Sindh, Pakistan. Pak. J. Biol. Sci. 12 (8): 648-652.

[39] Al-Berfkani M I, Zubair A I, and Bayazed H, 2014. Assessment of chlorine resistant bacteria and their susceptibility to antibiotic from water distribution system in Duhok province. J Appl Biol Biotechnol. 2: 010-013.

[40] Mohsen IH, Mohsen AH, Zaidan HK, Health effects of chlorinated water: a review article, 2019. Pak. J. Biotechnol. 16: 163-167. 
[41] Chowdhury S, 2012. Heterotrophic bacteria in drinking water distribution system: a review. Environmental monitoring and assessment. 84 (10): 6087-6137.

[42] Tesauro M, Bianchi A, Consonni M, Pregliasco F, Galli MG, 2010 Environmental surveillance of Legionella pneumophila in two Italian hospitals. Annali dell'Istituto superiore di sanit ̃̂. 46: 274-278.
[43] De Victorica J, Galván M, 2001. Pseudomonas aeruginosa as an indicator of health risk in water for human consumption. Water Science and Technology. 43 (12): 49-52.

[44] LeChevallier M W, Welch N J, and Smith D B, 1996. Full-scale studies of factors related to coliform regrowth in drinking water. Appl. Environ. Microbiol. 62 (7): 2201-2211. 